\title{
THE HERITAGE OF KAZAKH POETS AND ZHYRAUS (BARDS) IN THE TERRITORY OF KARAKALPAKSTAN
}

\author{
Tortkulbaeva T.A. \\ Doctor of Philosophy in Philological Sciences, Department of Kazakh language and literature, \\ Nukus state pedagogical institute named after Ajiniyaz, Nukus, Uzbekistan
}

Article DOI: https://doi.org/10.36713/epra6372

\begin{abstract}
There are analyzed characteristic features of Kazakh folklore which are performed by poets and zhyraus (bards) in the territory of Karakalpakstan. In this article we tried to analyze characteristic features of Kazakh folklore which are performed by poets and zhyraus (bards) in the territory of Karakalpakstan. The aim of this article is to reveal the peculiarities of coexistence and relations between Kazakh, Uzbek and Karakalpak folklore and literature on the base of studying the development of tutor-apprentice traditional methods of poetical and performing skills of Kazakh poets and zhiraus (performers of folk creative works-poems, eposes, etc. in the own accompaniment in dombra, a national two-stringed musical instrument) in Karakalpakstan.
\end{abstract}

KEYWORDS: Kazakh poets and jyraus; folklore; comparative analyses; national literature; regional literature; world literature; culture; interrelations; eposes and etc.

\section{INTRODUCTION}

Nowadays the method of comparative analysis dominates in the comparative-typological study of literary relations and literary interaction over the world. This method, often called "Veselovsky method", revealed literary traditions in many national literatures of the world are historically and genetically interconnected and developed in the context of mutual creative dialogue.

Indeed, advanced scientific and theoretical concepts of comparative literature allow to determine the literary relations of the fraternal peoples of the Central Asian region, including the principles of development of Kazakh folklore and literature living outside their historical homeland.

In today's world literature, the term "Kazakh folklore and literature" refers not only to Kazakhstan, but also to the whole literary and artistic heritage created by Kazakhs living in China, Mongolia, Turkey, Iran, Afghanistan, Uzbekistan, including Karakalpakstan. Therefore, the creative heritage of Kazakh poets living in Karakalpakstan plays a special role in the formation and development of such a whole literary and cultural heritage.

As a result of the synthesis of Eastern and Western literary relations and the study of the interaction of literary traditions in world literature, it was found that the literary heritage of each nation included the concepts of "national literature", "regional literature" and "world literature". The periodization and systematization of inter-literary relations laid the foundation for the formation of the theory of literary influence and creative assimilation. Such new theoretical views became the basis for identifying the area types of national literature, including the comparative-typological study of the literary heritage of the Kazakhs living in Karakalpakstan with the literature and folklore of the main region inhabited by this ethnos. Although the oral and written literature of the Kazakhs in the territory of Karakalpakstan is conditionally called by this name, in fact it is one of the local manifestations of the system of spiritual values that emerged on the basis of artistic and aesthetic thinking of the Kazakh people. 


\section{EPRA International Journal of Research and Development (IJRD)}

The historical and genetic basis of Kazakh folklore and literature is clarified through the comparative-typological study of the literary heritage of the Kazakhs of this region with the folklore and literature of the Turkic peoples living in the Aral Sea region.

\section{MATERIALS AND METHODS}

The policy of interethnic harmony, religious tolerance and solidarity pursued by the leadership of the Republic of Uzbekistan during the years of independence, including 2017-2019, is reflected in the socio-cultural life of these peoples. Due to the great opportunities created for all peoples living in our country to develop their national customs and traditions, receive education in their native language, and also literature, culture, language, folklore of every nation and people are widely studied and promoted. Indeed, "our focus will be on further developing the mutual friendship and solidarity that prevails in our society, ensuring equal rights for all citizens, regardless of nationality, religion or creed" [1]. The findings of the study of the literary heritage of the Kazakh people living in Karakalpakstan also serve to further develop friendship and cooperation between the fraternal peoples of the region.

It is well known that the principle of literary traditions and the role of literary relations have been increased during last years. The works of researchers as K.Mambetov, K.Kurambaev, K.Jumajanov, K. Aralbaev, G.Esirkepova, A.Bijanova, P.Allambergenova, K.Makhmudov, G.Gurambaeva and O.Geylyaev related to this topic have been studied and investigated.

It should be noted that Oqpan Aytek uli, Seydali Jumabek uli, Kazan zhirau, Karasay Kali uli, Tileumagambet Amanjolov, Lepes zhirau Amanturli uli, Zhakip zhirau, Jalgasbay Aralbaev, Kulkar Ametov, Serimbet, who lived and worked in Karakalpakstan in the second half of XIX century, and zhirau Muratbay Shonqaraev and more than thirty Kazakh poets and writers have not been studied yet from the point of view of literary heritage. Studying the relationships, traditions and individual poetic skills in Karakalpak-Kazakh poetry and jazz creativity will allow to cover the ways, genres, forms and artistic features of Kazakh literature in Karakalpakstan.

\section{RESULT AND DISCUSSION}

In this research there were analyzed the historical, national, spiritual and aesthetic bases of the formation of the heritage of Kazakh poets and bards in the Karakalpak land who had lived and created their masterpiece since the end of the XIX ${ }^{\text {th }}$ century and until the 60 s of the $\mathrm{XX}^{\text {th }}$ centuries. The literary heritage of the Kazakh poets living in the land of Karakalpakstan also took nourishment from that common source and developed.

The historical, national-spiritual, aesthetic roots of Kazakh folklore and literature in the territory of Karakalpakstan are the common literary and folklore heritage of the Turkic-speaking peoples. We confirm that the folklore and literature samples in the region have been studying are an ethno-areal, regional view of literature with Kazakh national folklore that has undergone various stages of development since the second half of the $19^{\text {th }}$ century. Both history and fiction deny that the people of the region have lived together since the time of the ancient Sak-Massaget, the Turkish Khanate, the Oguz-Pecheneg-Kipchak, the Golden Horde, the Nogai Horde.

The ancient brotherhood and friendship of the Kazakh-Karakalpak peoples began to become more visible in the history of the XVI-XVIII centuries. For example, since the second half of the 16th century, a large part of the Karakalpaks living in the middle and lower reaches of the Syrdarya became politically dependent on the Kazakhs. That period friendly relations were strengthened between Kazakh and Karakalpak people.

Professor K.Maksetov noted that in the XVIXVII centuries, due to the long-standing historical destiny, traditions and language of the KarakalpakKazakh peoples were developed and flourished. As a proof of this, we can see that there are many similarities in legends, fairy tales, fables, riddles and also in national songs - betashar, wedding traditions and elegies [5].

Having characterized this situation, academician R.Berdibaev said, "Most of poets and bards lived in the territory of Syr Darya and Amu Darya, namely in Karakalpakstan. Here the art of "bakhshi" was well-developed and as "epic region" Karakalpakstan was a place of a pure stream that provides very interesting, vital materials for Karakalpak folklorists [3].

We note that the legacy of the Kazakh poets and jiraus of Karakalpak region refers to the types and genres that already-existed core of Kazakh folklore and literature. They are based on the lyrics of traditional Kazakh folklore and literature dedicated to Navruz, Ramadan songs, badik (song type), wedding traditins, jar-jar, betashar, competitions, songs of farewell, fairy tales, legends, rhetoric, myths, epic genres ("Alpamis batyr", "Qoblandy batyr", "Er Targyn", "Kambar batir"), love epics ("Kozi Korpesh - Bayan sulu", "Qiz Jibek", "Ayman-Sholpan").

Apparently, many of these types of folklore are also presented in other peoples in the region. But they also have certain differences in each nation. Based on this, it is necessary to study in a typological direction the genres in the works of poets and jiraus 


\section{EPRA International Journal of Research and Development (IJRD)}

of the region, their repertoire, music and art of speech, their traditions and heritage in terms of the synthesis of folklore and literature. Interestingly, the terms used to describe folk performers in Karakalpakstan (jirau, poet, baxshi, qissaxon, janapayshi (student)) are the same in Kazakh.

It should be noted that the number of Kazakh poets who lived and worked in Karakalpakstan in the early nineteenth and early twentieth centuries is more than 30 , but depending on the scope of research, we can focus only on the most famous of them. For this reason, we approached the works of Seydali Jumabek ulu (1839-1928), Karasay Qali ulu (1848-1926), Tileumagambet Amanjol ulu (1860-1935) only on the basis of comparative analyses.

Karasay Qali ulu is one of the talents who led the art of poetry and bakhshi at once. He was born in 1848 in a place called "Samatay" near Manqishlak. When Karasay grows up, he becomes a pupil of wellknown bakhshis like Akkiyiz and Erman. Owing to them he learnt the art of bakhshilik. Well-known epic poems «Qoblandi Batir», «Qalmambet», «Alpamis» were performed in masterly fashion by him.

The lifelong friendship of Karasay Qali Ulu and Nurabulla and the similarities in their performances can be shawn in these lines of Karasay to Nurabylla:

Odan a'ri sorasan',

Alladan uris sorag'an.

Jerine kelgen dushpannin',

Moyinlarin burag'an.

Qanin suday ag'izg'an,

Qaraqipshaq Qobilandini,

Ba'rin ayt ta, birin ayt.

Nurabulla, shirag'im,

Qarasaydan qalg'an so'z.

El qorg'ag'an erlerdi ayt,

Erlerdin' erlik jirin ayt.

Seydali Jumabek ulu (1839-1928) was one of the bards (jirau) who gradually increased the art of baxshi to the status of pure poetry.

The poet not only became a compatriot of the Karakalpak poets of the time, but also collaborated with them. Seydali also praised the work of Karakalpak poets, whom he considered a teacher, and praised them:

A'jiniyaz - jitdin' du'ldili,

Berdaq - o'mir bu'lbili,

Tin'lap o'stim jasimnan,

Haliq u'nindey ha'r kuni.

Outstanding Karakalpak poets Berdaq, O’tesh, A'jiniyaz influenced to literary career of Seydali. Friendship between different nations (Karakalpak, Kazakh and Uzbek) are the topic in his works. For example:

\author{
Qaraqalpaq balasi, \\ A'yemdegi haliq edi, \\ O'zbek penen tag'dirles, \\ Bizin' qazaq balasi, \\ Dostina berik jan edi.
}

K. Jumajanov, a researcher of Kazakh literature in the Karakalpak region, noted these features of Seydali's work, saying that Kunkhoja, Ajiniyaz, Berdaq, and Otesh were his teachers after his uncle Eshim Axun, and listed them in tables with his photos [4].

According to K. Allambergenov, a leading scholar in the field of Karakalpak literature, the influence of Ajiniyaz's speech with Qiz-Men'esh is watched in all of Seydali's speeches [2].

However, the aytis (word-competition) between Seydali and Altyn was appeared after the aytis between Ajiniyaz and Kyz-Mengesh (18611862). So, the aytis between Altin and Seydali was nearly in 1869-1870. There are similarities in their structure, plot, and even some of the verses in this narration.

1. Aytis between Ajiniyaz and Qiz-Men'esh:

Astima mingen atim sur qara ker,

Sorg'alap sur qaradan ag'adi ter,

Mollalar ko'risiudi sunnet deydi,

Hojeke, ko'riseyik qolin'di ber.

2. Aytis between Seydali and Altin:

Astima mingen atim sur qara ker,

Ag'adi sur qaradan sorg'alap ter,

Korispek, qol alispaq - mindet, deydi,

Jolaushim, koriseyik, qolin'di ber.

The utterances of Kazakh poets in the region can be studied in three thematic areas:

1. The utterances of KazakhKarakalpak poets. It was called as "Friendship Talks" by K.Allambergenov;

2. Investigations by T.Tebegenov;

3. Inter-ethnic disputes (aytis) which include aytises "Kunkhoja and Sherniyaz poet", "QizMen'esh with Ajiniyaz", "Yrysty with Ajiniyaz", "Dame with Mansur", "Qulim with Tynim", "Seydali with Altin". These aytises are an invaluable phenomenon in Kazakh-Karakalpak literary relations.

It would be reasonably to confirm through the Kazakh folklore and literature being created and developed in the territory of the neighboring Karakalpak territory have not lost their national features and remained to be a competent property of the Kazakh people. That's why we made a particular accent to the problems of traditions, heredity, national colours and intercultural literary correlations and on the base of solving these important problems we succeeded to confirm that the whole literary and cultural inheritance of Kazakh poets and zhiraus of the above-mentioned period is the integral part of the Kazakh folklore and literature. So, we cannot 


\section{EPRA International Journal of Research and Development (IJRD)}

imagine the Kazakh folklore and literature without the enormous part created by Kazakh poets and zhiraus during the time of nearly two centuries in the territory of Karakalpakstan. The fact is also confirmed by the national spiritual-aesthetic peculiarities of these popular genres which are considered as a wealthy literary and cultural inheritance of the whole Kazakh people. New historical circumstances and new literary-cultural environment have had its proper voice; own style of writing, there were appeared new wordsmiths.

Taking into account these progressive factors, we have analyzed the examples of the Kazakh literature in the Karakalpak territory and the basic factors motivating the occurrence of this, literary phenomenon i.e. creative activities of Kazakh poets and zhiraus that have become the integral part of the whole Kazakh national literature.

In general, the main novelty is revealing the Karakalpak literary and cultural areas as the birth place of the part of the Kazakh literary world which includes a number of well-known masters of Kazakh artistic word as Kharasay Khaliy uli, Seydaliy Jumabek uli, Tilewmaghambet Amanjol uli and etc., who made a great contribution to this important course.

\section{CONCLUSION}

As a result of medieval historical and ethnocultural processes, the folklore performance and creativity of the Kazakh population, which settled in the region, has undergone a process of renewal in its genre structure, ideological and artistic features and poetic context under the influence of Karakalpak and Uzbek bakhshis;

The practical results of the study include:

- it was found that the heritage of Kazakh poets and jiraus of Karakalpakstan reflected not only the example of literary values that enriched the whole Kazakh literature, but also the harmony of folklore and individual creativity;

- the genre structure of the literary heritage of the Kazakh poets is classified and based on the enrichment of their epic repertoire under the influence of the epics performed by the Karakalpak bakhshi-zhiraus;

- the process of formation of a series of works based on a common epic plot as a result of the interaction and master-student relations of the epic singers of the Kazakh, Karakalpak, Uzbek and Turkmen peoples;

So, new information about the life and literary heritage of the Kazakh poets who lived and worked in the second half of the XIX century and the first half of the XX century have been introduced into scientific circulation.

\section{REFERENCES}

1. Mirziyoev Sh.M. Together we will build a free and prosperous democratic state of Uzbekistan. Tashkent: NMIU "Uzbekistan", 2016.

2. Allambergenov K. Aytis in Karakalpak literature. Nukus: Karakalpakstan, 1989.

3. Berdibaev R. Epos is masterpiece of people. Almati: Rauan, 1995.

4. Jumajanov $Q$. Kazakh Literature in Karakalpak region. Almati: Aris, 2006.

5. Maqsetov, Q. Jiraus and bards. Nukus: Karakalpakstan, 1995. 